\title{
KEANEKARAGAMAN JENIS VEGETASI STRATA SEMAK DI HUTAN PERLINDUNGAN KAWASAN BUKIT COGONG
}

\author{
Destien Atmi Arisandy ${ }^{1}$, Merti Triyanti ${ }^{2}$ \\ STKIP PGRI Lubuklinggau ${ }^{1,2}$ \\ destienatmiarisandy@gmail.com ${ }^{1}$
}

\begin{abstract}
ABSTRAK
Tujuan dari penelitian ini adalah untuk (1) mengetahui indeks keanekaragaman $\left(\mathrm{H}^{\prime}\right)$ vegetasi strata semak di Bukit Cogong, dan (2) mengetahui faktor lingkungan abiotik di Bukit Cogong. Penelitian ini menggunakan metode tanpa plot (Plotless) yang berpusat pada titik (Point Centered Quarter Method), dengan membuat 3 Area Kajian yaitu Area Kajian A, B dan C dengan masing-masing 10 Stand. Berdasarkan hasil penelitian yang telah dilakukan, rerata Indeks Keanekaragaman ( $\left.\mathrm{H}^{\prime}\right)$ vegetasi strata semak di Bukit Cogong adalah Area Kajian A sebesar 2,13, area kajian B memiliki rerata H' sebesar 1,77. Sedangkan Area Kajian C memiliki rerata H' sebesar 1,61. Suhu udara di Bukit Cogong antara 28,30C-300C, kelembaban udara $86 \%$ - $93 \%$, suhu tanah antara 27,30C29,60C, kelembaban tanah antara $8 \%$ - $17 \%$ dan derajat keasaman $(\mathrm{pH})$ tanah antara 6,3-6,7. Simpulan, yakni rerata $H^{\prime}$ area kajian A, B, dan C memiliki kategori sedang melimpah.
\end{abstract}

Kata Kunci : keanekaragaman, strata semak, hutan perlindungan, bukit cogong

\begin{abstract}
The research aims at (1) finding the diversity index $\left(H^{\prime}\right)$ of bushes vegetation stratum, and (2) abiotic environment factors at Cogong hill. This research used plotless method with Point Centered Quarter Method by classifying into three scopes, namely, research scope $A, B$ and $C$ with 10 items each. Based on the result, the diversity index average $\left(H^{\prime}\right)$ of bushes vegetation stratum at Cogong hill in research scope $A$ was 2,13; scope $B$ was 1,77 and scope $C$ was 1,61. The air temperature at Cogong hill was between 28,30C-300C, the air humidity was between $86 \%$ - $93 \%$, the soil temperature was between 27,30C-29,60C, the soil humidity was between $8 \%-17 \%$ and the soil scale of acidity $(\mathrm{pH})$ was between 6,3-6,7. In conclusion, the average of $H^{\prime}$ in scope $A, B$, and $C$ was in mediumabundant category.
\end{abstract}

Keywords : diversity, bushes stratum, protected forests, Cogong hill

\section{PENDAHULUAN}

Hutan adalah sarana pemenuhan kebutuhan manusia dan sebagai salah satu faktor pengendali iklim di dunia (Fitriana, 2008). Menurut Wiryono (2012) hutan adalah suatu ekosistem, yang terdiri dari komponen abiotik seperti udara, air, tanah, dan komponen biotik yang terdiri dari tumbuhan, hewan, dan mikroorganisme. Ekosistem hutan merupakan hubungan timbal balik antara 
makhluk hidup dengan lingkungannya. Hubungan ini terlihat dengan adanya variasi dalam jumlah masing-masing jenis tumbuhan dan terbentuknya struktur masyarakat tumbuh-tumbuhan tersebut. Terbentuknya pola keanekaragaman dan struktur spesies vegetasi hutan merupakan proses yang dinamis, erat hubungannya dengan kondisi lingkungan, baik biotik maupun abiotik.

Berdasarkan Surat Keputusan Menteri Kehutanan Nomor: 76/MenhutII/2001 tentang Penunjukkan Kawasan Hutan dan Perairan di Wilayah Provinsi Sumatera Selatan adalah Bukit Cogong dijadikan sebagai Hutan Lindung yang ada di Kapubaten Musi Rawas. Berdasarkan hasil observasi, diketahui bahwa Bukit Cogong terbagi menjadi tiga bagian yaitu Bukit Cogong I (Bukit Botak), Bukit Cogong II (Bukit Besar), dan Bukit Cogong III (Bukit Gatan). Diantara ketiga Bukit Cogong tersebut, Bukit Cogong II yang dijadikan sebagai tempat wisata oleh Pemerintah setempat dan sebagai objek penelitian. Bukit Cogong II merupakan kawasan hutan yang memiliki luas sebesar 1.222 Ha dimana terletak di Kabupaten Musi Rawas dan Kota Lubuklinggau. Bukit Cogong II terbagi menjadi tiga wilayah yaitu Hutan Pemanfaatan, Hutan Perlindungan dan Hutan Konservasi. Pemerintah Kabupaten Musi Rawas memberikan kepada Kelompok Tani untuk dikelola dan dimanfaatkan sebesar 290 Ha sebagai Hutan Kemasyarakatan (HKm) yang berdasarkan keputusan Bupati Musi Rawas No.389/KPTS/KEHUT/2015 tentang pemberian izin usaha pemanfaatan Hutan Kemasyarakatan (HKm). Hutan Kemasyarakatan Bukit Cogong terdiri dari Hutan Pemanfaatan (205 Ha) dan Hutan Perlindungan (85 Ha).

Hutan Perlindungan adalah areal hutan yang karena kondisi tertentu dilindungi keberadaannya oleh pemegang izin dan tidak dialokasikan untuk peruntukan lain dan sebagai habitat untuk penagkaran satwa (Kelompok Tani Hutan, 2015). Pengembangan dan pengelolaan Hutan Perlindungan di Bukit Cogong secara keseluruhan, tidak hanya flora dan fauna yang perlu diperhatikan tetapi juga habitatnya. Dengan demikian sangatlah diperlukan informasi ekologis yang benar mengenai habitat satwa di wilayah yang bersangkutan. Informasi ekologis yang diperlukan adalah densitas, frekuensi, dominansi dan indeks nilai penting (INP) penyusun vegetasi. Untuk mengetahui informasi ekologis komunitas hutan perlu dilakukan analisis vegetasi di wilayah bersangkutan.

Hutan memiliki vegetasi, menurut Yatim (1999) vegetasi adalah kumpulan

dari tumbuh-tumbuhan. Salah satu penyusun vegetasi adalah semak. Menurut Mandiri (2012) semak merupakan tumbuhan berkayu yang tingginya lebih dari satu meter, tetapi lebih rendah dari pada perdu dan hanya dahan-dahan utamanya saja yang berkayu. Hutan Lindung Bukit Cogong banyak terdapat vegetasi seperti pohon, semak, tiang, pancang, herba dan liana. Namun, jenis vegetasi strata semak di Bukit Cogong belum teridentifikasi keanekaragaman, struktur dan komposisi vegetasinya. Berdasarkan hal tersebut dilakukan penelitian dengan judul keanekaragaman jenis Vegetasi Strata Semak di Bukit Cogong, untuk 
mengetahui Indeks Keanekaragaman (H') vegetasi strata semak di Bukit Cogong, dan mengetahui faktor lingkungan abiotik di Bukit Cogong.

\section{METODE PENELITIAN}

Penelitian ini merupakan penelitian deskriptif kuantitatif. Penelitian ini menggunakan metode tanpa plot (Plotless) yang terpusat di titik (point-centered quarter method) atau metode kuadran. Dalam metode ini, empat jarak diukur tiaptiap titik sampling. Pada setiap titik dibuat empat kuadran (quarter) dengan membuat garis saling tegak lurus. Kemudian diukur jarak semak terdekat ke titik sampling dari masing-masing kuadran, kemudian dirata-rata (Wiryono, 2012).

Sampel penelitian ditetapkan dengan metode Purposive sampling. Metode ini merupakan metode penentuan sampel secara sengaja yang dianggap representatif (Fachrul, 2012) Secara keseluruhan luas area penelitian yaitu 17 ha atau $170.000 \mathrm{~m}^{2}$ yang diambil $20 \%$ dari keseluruhan luas seluruh lokasi penelitian (Irawati, 2014:11) dan luas area hutan perlindungan seluruhnya yaitu 85 ha atau $850.000 \mathrm{~m}^{2}$. Sehingga luas masing-masing area kajian $56.666 \mathrm{~m}^{2}$.

Pada masing-masing area kajian diletakkan 10 stand. Pada setiap stand penelitian diletakkan garis transek utama sepanjang $560 \mathrm{~m}$ dengan jarak antar stand yaitu 6,6 $\mathrm{m}$ dan dibuat 10 titik sampling yang memotong garis transek utama yang masing-masing berjarak 56 m.Pada setiap titik sampling ditentukan empat garis atau kuadran. Pada setiap kuadran ditentukan satu jenis semak yang mempunyai jarak terdekat dengan titik sampling. Semak yang dipilih kemudian dicatat jenisnya, diukur diameter batangnya dengan jangka sorong diatas permukaan tanah (Hairiah, 2011), dan jarak semak tersebut terhadap titik sampling. Masing-masing stand diukur keadaan abiotiknya, yaitu suhu tanah dengan menggunakan termometer, suhu udara dengan menggunakan termometer, $\mathrm{pH}$ tanah, kelembaban tanah dengan menggunakan soil tester dan kelembaban udara dengan menggunakan higrometer. Pengukuran faktor lingkungan abiotik di setiap stand dilaksanakan pada saat penelitian.

Parameter vegetasi semak yang dianalisis adalah Densitas, Densitas Relatif, Frekuensi, Frekuensi Relatif, Dominansi, Dominansi Relatif, dan Indeks Keanekaragaman (H'). Parameter vegetasi semak yang diperoleh saat penelitian adalah nama spesies, jarak spesies ke titik sampling, keliling batang dan diameter. Densitas adalah suatu perhitungan tentang jumlah individu di dalam suatu area (Putrawan, 2014). Pengukuran parameter vegetasi strata semak menggunakan rumus berikut:

\author{
Densitas i \\ Densitas Mutlak (DT) \\ Rata-rata jarak \\ Densitas Relatif (KR)
}

$$
\begin{aligned}
& =\frac{\text { Total jenis } i}{4 x \text { jumlah titik sampling }} \times D T \\
& =\frac{\text { Unit area }}{(\text { rata-rata jarak) }}{ }^{2} \\
& =\frac{\text { Total jarak }}{4 x \text { jumlah titik sampling }} \\
& =\frac{\text { Densitas } i}{\text { total densitas }} \times 100 \%
\end{aligned}
$$


Keterangan:

DT = densitas mutlak

$\mathrm{i} \quad=$ spesies

Frekuensi i

Frekuensi Relatif (FR)

Dominansi

$=\frac{\text { Jumlah titik sampling terdapat jenis } i}{\text { Jumlah titik sampling }}$

$=\frac{\text { Frekuensi } i}{\text { Total frekuensi }} \times 100 \%$

$=$ Rata basal area jenis $i X$ densitas $i$

Dominansi Relatif (DR)

$=\frac{\text { Dominansi } i}{\text { Total dominansi }} \times 100 \%$

Indeks keanekaragaman dihitung dengan menggunakan rumus Shanon atau Shannon index of general diversity (Fachrul, 2012).

$$
\mathrm{H}^{\prime}=-\sum\left\{\left(\frac{n i}{N}\right) \ln \left(\frac{n i}{N}\right)\right\}
$$

Keterangan:

$\mathrm{H}^{\prime} \quad$ = indeks keanekaragaman Shannon

ni $\quad=$ jumlah individu dari suatu spesies

$\mathrm{N} \quad=$ jumlah total individu

Menurut Fachrul (2012), besarnya Indeks Keanekaragaman jenis menurut Shannon-Wiener didefinisikan sebagai berikut:

1. Nilai H'> 3 menunjukkan bahwa keanekaragaman spesies pada suatu transek adalah melimpah tinggi.

2. Nilai $H^{\prime} 1 \leq H^{\prime} \leq 3$ menunjukkan bahwa keanekaragaman spesies pada suatu transek adalah sedang melimpah.

3. Nilai H' $<1$ menunjukkan bahwa keanekaragaman spesies pada suatu transek adalah sedikit atau rendah.

\section{HASIL PENELITIAN}

Berdasarkan penelitian yang telah dilaksanakan di areal hutan perlindungan hutan kemasyarakatan ( $\mathrm{HKm}$ ) Bukit Cogong diperoleh 16 spesies strata semak dengan hasil rerata Indeks Keanekaragaman (H') yang dapat dilihat pada Tabel 1 dibawah ini:

Tabel 1 Rerata H' pada Masing-Masing Jenis Semak pada Area Kajian A

\begin{tabular}{cccl}
\hline No & Stand & Area Kajian A & Kategori \\
\hline 1 & 1 & 1,58 & Sedang melimpah \\
\hline 2 & 2 & 1,44 & Sedang melimpah \\
\hline 3 & 3 & 1,66 & Sedang melimpah \\
\hline 4 & 4 & 1,17 & Sedang melimpah \\
\hline 5 & 5 & 1,54 & Sedang melimpah \\
\hline 6 & 6 & 1,93 & Sedang melimpah \\
\hline 7 & 7 & 2,30 & Sedang melimpah \\
\hline 8 & 8 & 1,80 & Sedang melimpah \\
\hline 9 & 9 & 1,73 & Sedang melimpah \\
\hline 10 & 10 & 1,55 & Sedang melimpah \\
\hline
\end{tabular}




\begin{tabular}{ccc}
\hline Jumlah & \multicolumn{2}{c}{16,70} \\
\hline Rerata H' & 1,67 & Sedang melimpah \\
\hline
\end{tabular}

Hasil pengukuran faktor lingkungan abiotik pada Area Kajian A dapat dilihat pada Tabel 2.

Tabel 2 Hasil Pengukuran Faktor Lingkungan Abiotik pada Area Kajian A

\begin{tabular}{ccccccc}
\hline \multirow{2}{*}{$\begin{array}{c}\text { Area } \\
\text { Kajian }\end{array}$} & Waktu & $\begin{array}{c}\text { Suhu } \\
\text { Udara } \\
\left({ }^{\mathbf{0}} \mathbf{C}\right)\end{array}$ & $\begin{array}{c}\text { Kelembaban } \\
\text { Udara }(\%)\end{array}$ & $\begin{array}{c}\text { Suhu } \\
\text { Tanah } \\
\left({ }^{0} \mathrm{C}\right)\end{array}$ & $\begin{array}{c}\text { pH } \\
\text { Tanah }\end{array}$ & $\begin{array}{c}\text { Kelembaban } \\
\text { Tanah (\%) }\end{array}$ \\
\hline \multirow{3}{*}{$\mathbf{A}$} & Pagi (06.00-10.00 WIB) & 28,6 & 92,3 & 27,6 & 6,3 & 16 \\
\cline { 2 - 7 } & Siang (10.00-14.00 WIB) & 29 & 92 & 28 & 6,6 & 10 \\
\cline { 2 - 7 } & Sore (14.00-18.00 WIB) & 28,6 & 88 & 28,6 & 6,7 & 8
\end{tabular}

Area Kajian B dengan ditemukan 12 spesies strata semak. Rerata Indeks keanekaragaman ( $\left.\mathrm{H}^{\prime}\right)$ dapat dilihat pada Tabel 3.Hasil analisis vegetasi strata semak pada Area Kajian B dengan rerata Indeks Keanekaragaman (H') yang berdasarkan kategori menurut Shannon-Wiener dapat dilihat pada Tabel 3.

Tabel 3 Rerata Indeks Keanekaragaman (H') pada Area Kajian B

\begin{tabular}{cccc}
\hline No & Stand & Area Kajian A & Kategori \\
\hline 1 & 1 & 1,63 & Sedang melimpah \\
\hline 2 & 2 & 1,60 & Sedang melimpah \\
\hline 3 & 3 & 1,22 & Sedang melimpah \\
\hline 4 & 4 & 1,46 & Sedang melimpah \\
\hline 5 & 5 & 1,39 & Sedang melimpah \\
\hline 6 & 6 & 1,45 & Sedang melimpah \\
\hline 7 & 7 & 1,14 & Sedang melimpah \\
\hline 8 & 8 & 1,33 & Sedang melimpah \\
\hline 9 & 9 & 0,88 & Sedikit melimpah \\
\hline 10 & 10 & 0,54 & Sedikit melimpah \\
\hline \multicolumn{5}{c}{ Jumlah } & & 12,64 \\
\hline \multicolumn{2}{c}{ Rerata H' } & 1,26 & Sedang melimpah
\end{tabular}

Hasil pengukuran faktor lingkungan abiotik pada Area Kajian A dapat dilihat pada Tabel 4

Tabel 4 Hasil Pengukuran Faktor Lingkungan Abiotik pada Area Kajian B

\begin{tabular}{ccccccc}
\hline \multirow{2}{*}{$\begin{array}{c}\text { Area } \\
\text { Kajian }\end{array}$} & Waktu & $\begin{array}{c}\text { Suhu } \\
\text { Udara } \\
(\mathbf{0} \mathbf{C})\end{array}$ & $\begin{array}{c}\text { Kelembaban } \\
\text { Udara }(\%)\end{array}$ & $\begin{array}{c}\text { Suhu } \\
\text { Tanah } \\
\left({ }^{0} \mathrm{C}\right)\end{array}$ & $\begin{array}{c}\text { pH } \\
\text { Tanah }\end{array}$ & $\begin{array}{c}\text { Kelembaban } \\
\text { Tanah }(\%)\end{array}$ \\
\hline \multirow{3}{*}{ B } & Pagi (06.00-10.00 WIB) & 28,6 & 93 & 27,6 & 6,4 & 15 \\
\cline { 2 - 7 } & Siang (10.00-14.00 WIB) & 30 & 86 & 29 & 6,3 & 16 \\
\cline { 2 - 7 } & Sore (14.00-18.00 WIB) & 28,3 & 92 & 27,3 & 6,7 & 10 \\
\hline
\end{tabular}


Area Kajian C dengan ditemukan 10 spesies strata semak. Rerata Indeks keanekaragaman $\left(\mathrm{H}^{\prime}\right)$ dapat dilihat pada Tabel 3.Hasil analisis vegetasi strata semak pada Area Kajian C dengan rerata Indeks Keanekaragaman (H') yang berdasarkan kategori menurut Shannon-Wiener dapat dilihat pada Tabel 5.

Tabel 5 Rerata Indeks Keanekaragaman (H') pada Area Kajian C

\begin{tabular}{|c|c|c|c|}
\hline No & Stand & Area Kajian A & Kategori \\
\hline 1 & 1 & 1,20 & Sedang melimpah \\
\hline 2 & 2 & 1,25 & Sedang melimpah \\
\hline 3 & 3 & 0,98 & Sedikit melimpah \\
\hline 4 & 4 & 0,82 & Sedikit melimpah \\
\hline 5 & 5 & 0,85 & Sedikit melimpah \\
\hline 6 & 6 & 1,58 & Sedang melimpah \\
\hline 7 & 7 & 0,50 & Sedikit melimpah \\
\hline 8 & 8 & 0,61 & Sedikit melimpah \\
\hline 9 & 9 & 1,09 & Sedang melimpah \\
\hline 10 & 10 & 1,04 & Sedang melimpah \\
\hline \multicolumn{2}{|c|}{ Jumlah } & 9,92 & \\
\hline \multicolumn{2}{|c|}{ Rerata H' } & 0,99 & Sedikit melimpah \\
\hline
\end{tabular}

Hasil pengukuran faktor lingkungan abiotik pada Area Kajian C dapat dilihat pada Tabel 6

Tabel 6 Hasil Pengukuran Faktor Lingkungan Abiotik pada Area Kajian C

\begin{tabular}{clccccc}
\hline \multirow{2}{*}{$\begin{array}{c}\text { Area } \\
\text { Kajian }\end{array}$} & Waktu & $\begin{array}{c}\text { Suhu } \\
\text { Udara } \\
(\mathbf{0} \mathbf{C})\end{array}$ & $\begin{array}{c}\text { Kelembaban } \\
\text { Udara }(\%)\end{array}$ & $\begin{array}{c}\text { Suhu } \\
\text { Tanah } \\
\left({ }^{0} \mathrm{C}\right)\end{array}$ & $\begin{array}{c}\text { pH } \\
\text { Tanah }\end{array}$ & $\begin{array}{c}\text { Kelembaban } \\
\text { Tanah (\%) }\end{array}$ \\
\hline \multirow{3}{*}{$\mathbf{C}$} & Pagi (06.00-10.00 WIB) & 28,3 & 92,3 & 27,6 & 6,3 & 17 \\
\cline { 2 - 7 } & Siang (10.00-14.00 WIB) & 30 & 86 & 29 & 6,5 & 12 \\
\cline { 2 - 7 } & Sore (14.00-18.00 WIB) & 28,6 & 92,3 & 27,6 & 6,3 & 17 \\
\hline
\end{tabular}

Hasil Analisis vegetasi strata semak yang terdapat pada Area Kajian A, B dan $\mathrm{C}$ dengan rerata Indeks Keanekaragaman (H') dapat dilihat pada Tabel 7

Tabel 7 Rerata H' pada Masing-Masing Area Kajian

\begin{tabular}{ccccc}
\hline \multirow{2}{*}{ No } & Stand & \multicolumn{3}{c}{ Area Kajian } \\
\cline { 3 - 5 } & & $\mathbf{A}$ & $\mathbf{B}$ & $\mathbf{C}$ \\
\hline 1 & 1 & 1,58 & 1,63 & 1,20 \\
\hline 2 & 2 & 1,44 & 1,60 & 1,25 \\
\hline 3 & 3 & 1,66 & 1,22 & 0,98 \\
\hline 4 & 4 & 1,17 & 1,46 & 0,82 \\
\hline 5 & 5 & 1,54 & 1,39 & 0,85 \\
\hline 6 & 6 & 1,93 & 1,45 & 1,58 \\
\hline 7 & 7 & 2,30 & 1,14 & 0,50 \\
\hline
\end{tabular}




\begin{tabular}{ccccc}
\hline 8 & 8 & 1,80 & 1,33 & 0,61 \\
\hline 9 & 9 & 1,73 & 0,88 & 1,09 \\
\hline 10 & 10 & 1,55 & 0,54 & 1,04 \\
\hline & Jumlah & $\mathbf{1 6 , 7 0}$ & $\mathbf{1 2 , 6 4}$ & $\mathbf{9 , 9 2}$ \\
\hline & Rerata H' & $\mathbf{1 , 6 7}$ & $\mathbf{1 , 2 6}$ & $\mathbf{0 , 9 9}$ \\
\hline & Kategori & $\begin{array}{c}\text { Sedang } \\
\text { Melimpah }\end{array}$ & $\begin{array}{c}\text { Sedang } \\
\text { Melimpah }\end{array}$ & $\begin{array}{c}\text { Sedikit } \\
\text { Melimpah }\end{array}$ \\
\hline
\end{tabular}

Sedangkan grafik rerata INP pada Area Kajian A, B, dan C dapat dilihat pada gambar 1 .

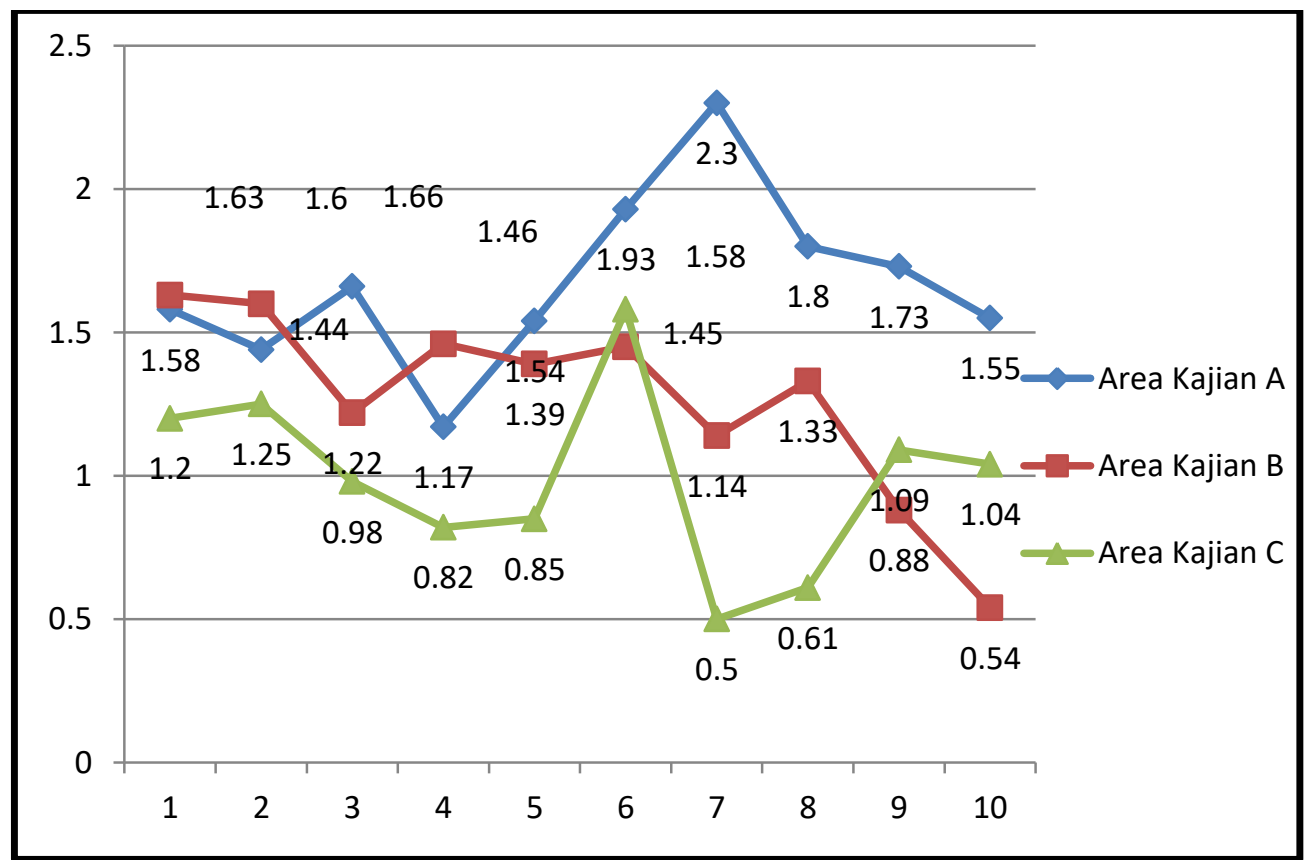

Gambar 1. Rerata H' pada Area Kajian A, B, dan C

\section{PEMBAHASAN}

Penelitian ini dilaksanakan di Hutan Lindung Bukit Cogong. Bukit Cogong adalah nama suatu kelompok Hutan Lindung (HL) yang terletak di Kabupaten Musi Rawas dan Kota Lubuklinggau Propinsi Sumatera Selatan. Wilayah Hutan Lindung Bukit Cogong sebagian besar termasuk dalam wilayah administrasi Desa Sukakarya Kecamatan STL. Ulu Terawas Kabupaten Musi Rawas (Cahyono, 2013). Penelitian ini menggunakan metode tanpa plot (Plotless) yang berpusat pada titik (Point Centered Quarter Method). Metode Point Centered Quarter (PCQ) adalah metode pengukuran jarak yang dilakukan dari titik sampling ke tumbuhan (semak) dan dengan metode empat jarak diukur tiaptiap titik sampling. Pada setiap titik dibuat empat kuadran (quarter) dengan membuat garis saling tegak lurus. Kemudian dirata-rata (Wiryono, 2012). Metode PCQ memiliki kelebihan dan kelemahan, dimana kelebihannya adalah dalam pelaksanaannya memerlukan waktu yang sedikit, mudah dan lebih cepat untuk mengetahui komposisi dan dominansi. Sedangkan kelemahannya adalah tidak 
dapat digunakan untuk populasi vegetasi yang pengelompokkannya tinggi atau menempati ruang secara seragam (Soegianto, 1994).

Pada area kajian A merupakan area yang terletak dipangkal area perlindungan yang berdekatan dengan area wisata bukit cogong atau area pemanfaatan pada area kajian A dibatasi dengan batu-batuan besar dan sungai. Area kajian B merupakan area yang kedua yang terletak ditengah areal perlindungan hutan kemasyarakatan $(\mathrm{HKm})$ Bukit Cogong Kabupaten Musi Rawas. Sedangkan, area kajian $\mathrm{C}$ merupakan area penelitian yang ketiga yang dijadikan sebagai tenpat penelitian. Area kajian $\mathrm{C}$ terletak di ujung areal perlindungan yang berdekatan dengan jalan setapak yang ada di area perlindungan. Jenis vegetasi strata semak yang banyak ditemukan pada ketiga area kajian ini adalah sama yaitu seduduk lanang (Clidemia hirta). Tumbuhan ini merupakan tumbuhan tahunan yang tangguh, perakaran kuat, batangnya keras bila ditebas akan tumbuh tunas-tunas baru (Faisal, 2011). Sedangkan menurut Palijama (2012) Clidemia hirta hidup pada tempat yang ternaungi (teduh) dan memiliki $\mathrm{pH}$ tanah yang bersifat asam. Selain itu, tumbuhan ini merupakan tumbuhan yang termasuk kedalam ordo Myrtales, family Melastomataceae. Clidemia hirta merupakan tumbuhan yang sering dijumpai di tepi hutan, semak belukar, di tepi jurang, daerah terbuka, memiliki daun yang lebat sehingga sinar matahari yang mengenai permukaan tanah sedikit dan menyebabkan kelembaban tanah tinggi. Tumbuhan berdaun lebar yang cenderung tumbuh dengan habitat ternaungi (Palijama, 2012). Memiliki kandungan kimia seperti saponin, terpen, dan alkaloid pada buah (Manalu, 2014).

Tumbuhan Clidemia hirta dapat menghasilkan lebih dari 500 buah yang berwarna biru-hitam pertahun. Masing-masing buah mengandung lebih dari 100 biji dan hidup pada $\mathrm{pH}$ yang asam dengan kondisi cuaca yang teduh (Binggeli, 2005). Penyebaran biji dapat dilakukan dari burung pemakan buah manusia dan dari buah yang jatuh ketanah. Penyebaran melalui biji dan didukung oleh manusia ataupun hewan dapat menyebabkan pertumbuhan tanaman ini dapat tumbuh semakin cepat dan dibantu dengan kondisi $\mathrm{pH}$ tanah, kelembaban tanah serta cahaya yang sangat mendukung membuat Clidemia hirta untuk tumbuh cepat dan mendominasi tempat yang ditempati. Ini disebabkan karena banyaknya unsur $\mathrm{N}$ yang diserap sehingga pertumbuhannya cepat (Palijama, 2012). Menurut Wirabuana (2015) suhu udara yang mendukung untuk Clidemia hirta adalah $20,74{ }^{0} \mathrm{C}-25,7{ }^{0} \mathrm{C}$ dengan kelembaban udara $72,6 \%-85,6 \%$. Clidemia hirta dapat dilihat pada gambar 6 di bawah ini: 


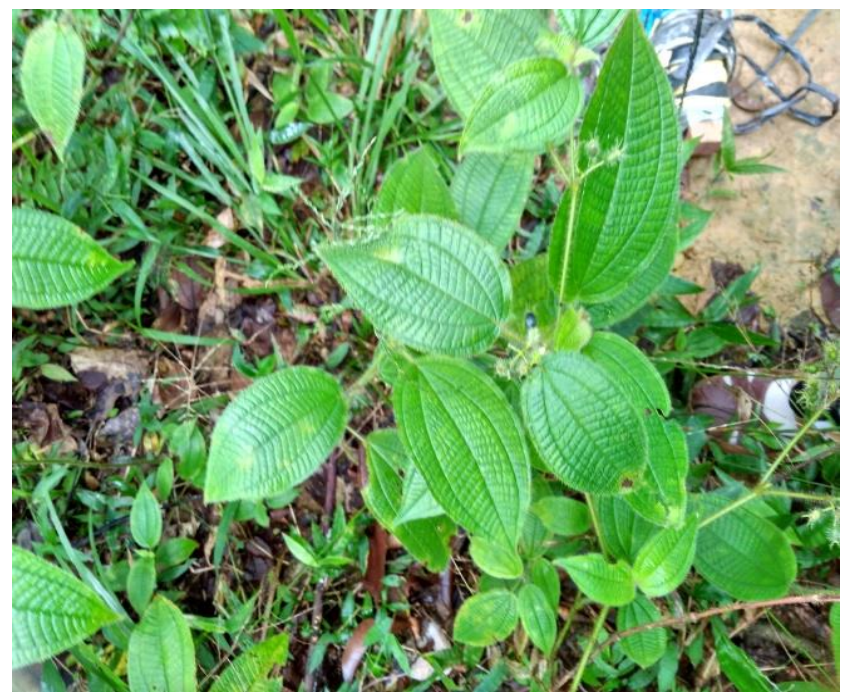

Gambar 2. Seduduk lanang (Clidemia hirta)

(Sumber: Dokumentasi Peneliti, 2017)

Berdasarkan rerata indeks keanekaragaman (H'), area kajian A memiliki nilai paling tinggi dan memiliki kategori sedang melimpah yaitu sebesar 1, 67 . Hal ini dapat disebabkan oleh banyaknya jenis vegetasi strata semak yang ditemukan pada area kajian A yaitu sebanyak 16 jenis. Sedangkan area kajian C ditemukan jenis vegetasi strata semak paling sedikit yaitu 10 jenis. Hal ini berpengaruh terhadap rerata indeks keanekaragaman, sehingga area kajian $\mathrm{C}$ memiliki nilai H' paling rendah dengan memiliki kategori sedikit melimpah dengan nilai H' sebesar 0,99. Menurut Fachrul (2012), jika nilai H' $1 \leq H^{\prime} \leq 3$ menunjukkan bahwa keanekaragaman spesies pada suatu transek adalah sedang melimpah. Sedangkan, jika nilai $H^{\prime}<1$ menunjukkan bahwa keanekaragaman spesies pada suatu transek adalah sedikit atau rendah. Hal ini juga sesuai dengan pendapat Indriyanto (2012) yang menyatakan bahwa suatu komunitas dikatakan memiliki keanekaragaman yang rendah atau sedikit jika komunitas itu disusun oleh sedikit spesies dan jika hanya ada sedikit spesies saja yang dominan. Sedangkan menurut Azizah (2017) sedikit atau rendahnya tingkat keanekaragaman jenis tumbuhan baik pohon, tiang ataupun semak menunjukkan bahwa di kawasan tempat berada tumbuhan tersebut rentan terhadap gangguan. Gangguan ini terlihat pada area kajian $\mathrm{C}$ yaitu berupa adanya jalan setapak. Hal ini menyebabkan berkurangnya daerah penyebaran dari jenis vegetasi strata semak. Sehingga jenis vegetasi strata semak yang ditemukan pada area kajian C paling sedikit dibandingkan area kajian A dan B.

Pada penelitian ini juga diukur faktor abiotik berupa suhu udara, kelembaban udara, $\mathrm{pH}$ tanah, suhu tanah dan kelembaban tanah. Pengukuran kelembaban tanah dan $\mathrm{pH}$ tanah dilakukan dengan menggunakan alat soil tester. Suhu udara dan suhu tanah menggunaan termometer dan pengukuran kelembaban udara menggunakan higrometer. Suhu di suatu tempat di muka bumi merupakan fungsi dari besarnya radiasi panas matahari yang mencapai tempat itu. Suhu di 
suatu tempat mempengaruhi tumbuhan dan hewan ditempat itu (Wiryono, 2009). Selain itu kelembaban udara dipengaruhi oleh jumlah dan jenis vegetasi, ketinggian, curah hujan, suhu dan angin. Kelembaban udara merupakan jumlah kandungan air yang terdapat di udara dapat berasal dari air transpirasi tumbuhan maupun penguapan yang berasal dari air di permukaan tanah. Uap air yang dilepaskan tumbuhan maupun uap air yang berasal dari air di permukaan tanah berpengaruh terhadap kelembaban udara di daerah tersebut (Irawati, 2014).

Suhu udara di areal perlindungan hutan kemasyarakatan $(\mathrm{HKm})$ Bukit Cogong berkisar $28,6^{\circ} \mathrm{C}-30^{\circ} \mathrm{C}$ dengan kelembaban udara berkisar $86 \%-93 \%$. Menurut Indriyanto (2012) tanah adalah tubuh alam yang berasal dari berbagai campuran hasil pelapukan oleh iklim dan terdiri atas komposisi bahan organik dan anorganik yang menyelimuti bumi, sehingga mampu menyediakan air, udara, dan hara bagi tumbuhan, serta sebagai tempat berdiri tegaknya tumbuh-tumbuhan. Suhu tanah di areal perlindungan hutan kemasyarakatan $(\mathrm{HKm})$ Bukit Cogong berkisar $27,3^{\circ} \mathrm{C}-29^{\circ} \mathrm{C}$ dengan kelembaban tanah berkisar $8 \%-17 \%$. Seperti yang dikemukakan oleh Wiryono (2009) bahwa secara umum, ketersediaan hara cukup baik pada $\mathrm{pH}$ sekitar 7. Tanah hutan umumnya bersifat masam, dengan $\mathrm{pH}$ di bawah 7 antara 4-6,7. Derajat keasaman pada tanah di areal perlindungan hutan kemasyarakatan (HKm) Bukit Cogong berkisar 6,3-6,7, dengan demikian faktor lingkunagan abiotik di areal perlindungan hutan kemasyarakatan (HKm) Bukit Cogong sesuai untuk pertumbuhan sebagian besar tumbuhan yang ada di areal tersebut.

\section{SIMPULAN}

Berdasarkan penelitian yang telah dilakukan, dapat disimpulan bahwa rerata indeks Keanekaragaman (H') tertinggi jenis vegetasi strata semak di Bukit Cogong adalah pada Area Kajian A dengan nilai sebesar 1,67 yang memiliki kategori sedang melimpah. Sedangkan rerata indeks Keanekaragaman (H') terendah pada Area Kajian C dengan nilai sebesar sebesar 0,99 dan berkategori sedikit melimpah. Sedangkan faktor lingkungan abiotik terukur adalah suhu udara berkisar $28,3^{0} \mathrm{C}-30^{\circ} \mathrm{C}$, kelembaban udara berkisar $86 \%-93 \%$, $\mathrm{pH}$ tanah berkisar 6,3-6,7, dan suhu tanah berkisar $27,3^{\circ} \mathrm{C}-29^{\circ} \mathrm{C}$ serta kelembaban tanah berkisar $8 \%-17 \%$.

\section{DAFTAR PUSTAKA}

Azizah, P.N. (2017). Analisis Vegetasi di Kawasan sekitar Mata Air Ngembel, Kecamatan Pajangan, Kabupaten Bantul. Jurnal Riset Daerah, 16(1), 2685-2702.

Binggeli, P. 13 Maret 2017. Crop Protection Compendium-Clidemia hirta (L.)

D. www.mikepalmer.co.uk

Cahyono, E. (2013). Valuasi Ekonomi Hutan Lindung Bukit Cogong Kabupaten Musi Rawas Provinsi Sumatera Selatan. Tesis. Bengkulu. Universitas 
Bengkulu. Program Studi Pascasarjana Pengelolaan Sumberdaya Alam dan Lingkungan (s-2). Fakultas Pertanian.

Fachrul, M. F. (2012). Metode Sampling Bioekologi. Jakarta: Bumi Aksara.

Faisal, R. Siregar, E. B. M. \& Anna, N. 05 April 2017. Inventarisasi Gulma pada Tegakan Tanaman Muda Eucalyptus spp. https://jurnal.usu.ac.id

Fitriana, R. (2008). Mengenal Hutan. Bandung: CV Putra Setia.

Hairiah, K. (2011). Pengukuran Cadangan Karbon dari Tingkat Lahan ke Bentang Lahan. Petunjuk Praktis. Edisi kedua. Bogor, World Agroforestry Centre, ICRAF SEA Regional Office, University of Brawijaya (UB), Malang, Indonesia xxp.

Indriyanto. (2012). Ekologi Hutan. Jakarta: PT Bumi Aksara.

Irawati, H. (2014). Analisis Vegetasi Strata Pohon di Sepanjang Sempadan Sungai Code Yogyakarta. Jurnal BIOEDUKATIKA, 2 (1), hal 10-15.

Kelompok Tani Hutan Wana Manungga. (2015). Rencana Umum Hutan Kemasyarakatan HLBC. Kabupaten Musi Rawas.

Manalu, V. C. Afifuddin Y. \& Marpaung L. (2014). Ekspolarasi Tumbuhan Beracun di Cagar Alam Dolok Tinggi Raja Kabupaten Simalungun Sumatera Utara. Prodi Kehutanan Fakultas Kehutanan Universitas Sumatera Utara. 1-10

Mandiri. T. K. T. (2012). Pedoman Bertanam Buah Naga. Bandung: CV. Nuansa Aulia.

Palijama, W., Riry, J \& Wattimena A. Y. (2012). Komunitas Gulma pada Pertanaman Pala (Myristica fragrans. $H$ ) Belum Menghasilkan dan Menghasilkan di Desa Hutumuri Kota Ambon. Jurnal Agrologia, 1 (2), 134-142.

Putrawan, I. (2014). Konsep-konsep dasar Ekologi Dalam Berbagai Aktivitas Lingkungan. Bandung: Alfabeta.

Soegianto, A. (1994). Ekologi Kuantitatif. Surabaya: Usaha Nasional.

Surat Keputusan Menteri Kehutanan Nomor: 76/Menhut-II/2001

Wirabuana, P. Y. A. P. (2015). Distribusi dan Asosiasi Tumbuhan Bawah clidemia hirta di Kawasan Resort Cibodas Taman Nasional Gunung Gede Pangrango. Tesis. Program Pascasarjana Program Studi Ilmu Kehutanan Fakultas Kehutanan. Universitas Gadjah Mada Yogyakarta.

Wiryono. (2012). Ekologi Hutan. Bengkulu: UNIB Press.

Yatim, W. (1999). Kamus Biologi. Bandung: Yayasan Pustaka Obor Indonesia. 